\title{
Assessment of Heavy Metals Concentration and Health Risks of Selected Vegetables Sold In Jos Metropolis
}

Olufunso Adeniyi ${ }^{1 *}$, David Bayo ${ }^{1}$, Adebayo Adeniyi ${ }^{2}$, Kingsley Okeke-Agulu ${ }^{1}$

${ }^{1}$ Montane Forest Research Station, Forestry Research Institute of Nigeria, P.M.B. 2019, Jos, Plateau State, Nigeria.

${ }^{2}$ Department of Animal Production, Faculty of Agriculture, University of Jos, P.M.B. 2084, Jos, Plateau State, Nigeria.

*Corresponding author: Olufunso Adeniyi, Montane Forest Research Station, Forestry Research Institute of Nigeria, P.M.B. 2019, Jos, Plateau State, Nigeria;

Received date: July 26, 2021; Accepted date: Augusł 23, 2021; Published date: Augusł 30, 2021

Citation: Olufunso Adeniyi, David Bayo, Adebayo Adeniyi, Kingsley Okeke-Agulu(2021) Assessment of Heavy Metals Concentration and Health Risks of Selected Vegetables Sold In Jos Metropolis. Archives of Medical Case Reports and Case Study. 4(5); DOI:10.31579/2694-0248/072

Copyright: () 2021 Olufunso Adeniyi, This is an open access article distributed under the Creative Commons Attribution License, which permits unrestricted use, distribution, and reproduction in any medium, provided the original work is properly cited.

\begin{abstract}
This study revolved around environmental pollution caused by heavy metals and the health risks posed to humans by the consumption of contaminated vegetables commonly sold in Jos, Nigeria. Vegetables studied (Apium graveolens - Celery, Hibiscus cannabinus - kenaf, Hibiscus sabdariffa - Sorrel or Roselle, Allium fistulosum - Spring Onions leaves and bulbs, Sesamum radiatum - Sesamum leaves) were obtained from major markets within Jos metropolis. They were washed, air-dried, homogenized, and stored in air-tight bottles. Their concentrations of heavy metals ( $\mathrm{Zn}$, $\mathrm{Fe}, \mathrm{Mn}, \mathrm{As}, \mathrm{Cd}, \mathrm{Pb}, \mathrm{Cr}$, and $\mathrm{Cu}$ ), were determined using a graphite furnace atomic absorption spectrophotometer, and their health risks were evaluated through daily intake and hazard quotient. The vegetables analyzed gave different concentrations of heavy metals with their values falling within the FAO/WHO permissible limits. The highest concentration of Iron $(0.515 \pm 0.003 \mathrm{mg} / \mathrm{kg})$ and Cadmium $(0.095 \pm 0.006 \mathrm{mg} / \mathrm{kg})$ were found in Celery, while Kenaf had the highest copper $(0.030 \pm 0.008 \mathrm{mg} / \mathrm{kg})$ concentration. Zinc was higher in all the vegetables when compared to the other metals. The daily intake values of all the metals examined exceeded the maximum tolerable daily intake (MTDI) except for copper. Hazard quotient values of all the metals were less than 1 except As, $\mathrm{Cd}$, and $\mathrm{Zn}$ which were found to be greater, thereby signifying health risk potentials of these metals. The study, therefore, revealed that consumption of these vegetables could constitute potential health hazards to the well-being of the consumers.
\end{abstract}

Keywords: daily intake; environmental pollution; hazard quotient; health risk; heavy metals concentration; vegetables

\section{Abbreviations}

WHO - World Health Organization

FAO - Food and Agriculture Organization

MTDI -Maximum Tolerable Daily Intake

NIMET - Nigerian Meteorological Agency

AOAC - Association of Official Chemists

DIM - Daily intake of metals

US EPA - United States Environmental Protection Agency

HQ - Hazard quotient

DIV - Daily intake of vegetables

Cmetal - Concentration of metal in the vegetable
Bo - Human body weight

RfD - Oral reference dose for metals

ASTDR - Agency for Toxic Substances and Disease Registry

$\mathrm{Fe}-$ Iron

$\mathrm{Cu}$ - Copper

As - Arsenic

$\mathrm{Cd}-$ Cadmium

$\mathrm{Zn}-\mathrm{Zinc}$

$\mathrm{Pb}-$ Lead

Mn - Manganese

$\mathrm{Cr}-$ Chromium 


\subsection{Introduction}

Vegetables are the fresh and consumable parts of herbaceous plants (Mafuyai et al., 2019). They are known to play an important role in human nutrition as they are sources of minerals, vitamins, dietary fibers, and phytochemicals to name a few. They are used to improve soup quality, also used as preventive and curative measures against diseases by acting as antioxidants, phytoestrogens, and anti-inflammatory agents (Slavin and Lloyd, 2012; Egharevba et al., 2017). Adults and children are advised to consume vegetables regularly because they add variety and flavor to food and are also required for a healthy diet (Skerrett and Willett, 2010; Njoku et al., 2017).

Heavy metals are trace metals that can be poisonous at low concentrations. They are deleterious to human health (Jaishankar et al., 2014) and usually have a density that is about five times the density of water (Bedassa et al., 2017). They are naturally present in the earth crust (Jaishankar et al., 2014) and can be released through natural weathering processes and anthropogenic activities such as mining, smelting of metal scraps, use of agrochemicals, sludge dumping, exhaust from vehicles among others (Tchounwou et al., 2012; Ogundiran and Osibanjo, 2008). They have become a crucial environmental issue as they are one of the major contaminants of food supply among a vast array of environmental pollutants. They are persistent, non-biodegradable (Singh et al., 2011), and toxic as they have the potential to bio-accumulate in different organs of the body thereby causing side effects which are grossly injurious. Though heavy metals are useful industrially, the consumption of food plants (such as vegetables) grown in metal contaminated soil is a source of exposure to these toxic metals (Bedassa et al., 2017). Other sources include drinking contaminated water, dust inhalation, direct ingestion of polluted soil (Dafaelseed et al., 2007), use of contaminated irrigation water, pesticide application (Onakpa et al., 2018), and vehicle emission. Some cases of poisoning through exposure to heavy metals have been reported in Nigeria, they include the Zamfara lead poisoning and increase in cancer prevalence among the populace (Bayo et al., 2021).

Jos is the administrative capital city of Plateau State in central Nigeria; it has a climate that is more temperate than other parts of the country (Lenka et al., 2018), this has enabled the growth of exotic fruits and vegetables. Most of the farmers depend heavily on agrochemicals (Lenka et al., 2018) and convey their vegetables to markets within Jos and neighboring cities for sale. Jos was also known for large-scale tin mining during the precolonial era; this has left a lot of abandoned mining ponds in various settlements within the city (Joseph et al., 2016; Lar et al., 2014).

Heavy metals contaminate vegetables when their concentrations are greater than the permissible limits. They may be deposited on surfaces of vegetables and then absorbed into the tissues (Singh et al., 2011) thereby bio-accumulating. This can cause clinical problems in men and animals (Lenka et al., 2018) that consume such vegetables. As a result of the dearth of scientific information, this research aimed to evaluate the concentration of some heavy metals in the vegetables commonly consumed in Jos Nigeria, not undermining their comparison to WHO/FAO limits and health risks.

\subsection{Materials and Methods}

\subsection{Study Area:}

This study was carried out within the city of Jos, Plateau State, Nigeria. Jos is found within $9^{\circ} 56^{1} \mathrm{~N}$ and $8^{\circ} 53^{1} \mathrm{E}$; it lies on the Delimi River, it is about $1280 \mathrm{~m}$ above sea level with an average monthly temperature of $21^{\circ} \mathrm{C}-25^{\circ} \mathrm{C}$ and annual rainfall of about $1400 \mathrm{~mm}$ (NIMET, 2017; Lenka et al., 2018; Bayo et al., 2021). A lot of mining activities by foreign companies and other small-scale artisans started in Jos (and Plateau State as a whole) around the colonial era, these have left a lot of waste dumps and ponds that are no longer in use. Most of these ponds now serve as irrigation channels for watering crops planted by the farmers. The mining activities also led to the contamination of the environment by metals that were released unto the surface (Joseph et al., 2016; Lenka et al., 2018). Wastewater from other industries within the metropolis is also channeled into streams which some farmers use for irrigation (Dabak et al., 2013; Bayo et al., 2021). Farmers around Jos are also known to collect manure, inorganic fertilizers, town refuse ash, and farm waste ash. They combine all these and use them as manure to improve soil fertility; these eventually raise the concentration of heavy metals in the soils on which vegetables are grown (Egharevba et al., 2017).

\subsection{Sample Collection and Preparation:}

Fresh samples of five (5) vegetables were purchased from five (5) major markets located in Jos. The markets include the Building materials (Express) market, Farin gada market, Bukuru (Kugia) market, Terminus market, and Fobur market. Each of the vegetables was randomly purchased from three (3) traders in each of the markets; they were placed in labeled polythene bags and taken to the laboratory (Adedokun et al., 2016; Alliea, 2014; Bayo et al., 2021).

These vegetables are majorly consumed in some parts of northern Nigeria but they are lesser-known and underutilized in other parts of the country. They were washed with tap and distilled water on reaching the laboratory to remove unwanted adhered particles. Each of the vegetables was made into a composite sample; edible parts (leaves and stalks) were cut into smaller pieces with a stainless knife and air-dried for about two weeks. They were later homogenized using a grinder, stored in air-tight bottles, and labeled. Representative samples were subsequently analyzed.

\subsection{Digestion of Samples:}

$0.2 \mathrm{~g}$ of the homogenized vegetable samples were weighed separately into dried Kjeldhal flasks; $1 \mathrm{~mL}$ perchloric acid and $5 \mathrm{~mL}$ nitric acid were added to each of the flasks, the mixtures were stirred and boiled on a Kjeldhal heater in a fume cupboard. They were later cooled; the content of each flask was filtered into a $100 \mathrm{~mL}$ volumetric flask and diluted to mark with deionized water.

\subsection{Heavy Metals Analyses:}

Each solution was separated into triplicates in sample bottles for metal analyses. The concentrations of the following heavy metals (copper, arsenic, zinc, lead, iron, manganese, chromium, and cadmium) were determined using a graphite furnace atomic absorption spectrophotometer - PG500, PG Instruments Ltd., Leicestersire, England (AOAC, 1975; Bayo et al., 2021).

\subsection{Determination of Oral Intake of Metals:}

This was calculated using the method of Cui et al. (2004) as described by Jolly et al. (2013) and Lar et al. (2014).

Daily intake of metals $($ DIM $)=$ daily vegetable consumption $x$ mean vegetable metal concentration ( $\mathrm{mg} /$ day, fresh weight)

The recommended amount of vegetables in man's daily diet is $300-350 \mathrm{~g}$ per person (WHO, 2001). Lar et al. (2014) however estimated a value of $61.5 \mathrm{~g} /$ day as the vegetable consumed by Nigerians because Africans consume fewer amounts of vegetables.

\subsection{Determination of health risk index of metal contamination of vegetables:}

The risk posed on human health as a result of consuming metalcontaminated vegetables was calculated using the United States Environmental Protection Agency (US EPA, 1989) Hazard Quotient (HQ) as described by Jolly et al. (2013) and Lar et al. (2014). If the hazard quotient is lower than one (1), no risks would be observed. Hazard quotient is calculated using the following equation: 
$H Q=\frac{\text { Div } \times \text { Cmetal }}{R f D \times B o}$

Where Div = daily intake of vegetables or DIM - the daily intake of metal through the vegetables (mg/day); Cmetal = concentration of metal in the vegetable $(\mathrm{mg} / \mathrm{kg}) ; \mathrm{Bo}=$ human body weight $(\mathrm{kg})$; an average human weight of $65 \mathrm{~kg}$ for an average adult has been assumed (Jolly et al., 2013; Lar et al, 2014). RfD = oral reference dose for metals $(\mathrm{mg} / \mathrm{kg}$ of body weight/day), Arsenic - 0.0003, Cadmium - 0.0010, Chromium - 0.0030, Copper - 0.0400, Iron - 0.7000, Lead - 0.0040, Manganese- 0.1400 and Zinc - 0.3000 mg/kg/day (US EPA, 1997; Cui et al., 2004; Wilbur et al., 2008; Sharma et al., 2016; US EPA, 2015; RSL, 2020; Bayo et al., 2021).

\subsection{Statistical Analysis:}

Data were analyzed using descriptive statistics (measurement of central tendency and dispersion).

\subsection{Results and Discussion}

\subsection{The concentration of Heavy Metals in the Vegetable Samples:}

Figure 1 shows that the mean concentration of heavy metals varied among the different vegetables analyzed, while Table 3 shows the FAO/WHO permissible limits to which they were compared. Most of the metals fell within the limits; Celery had the highest concentration of iron $(0.515 \pm 0.003 \mathrm{mg} / \mathrm{kg})$ and cadmium $(0.095 \pm 0.006 \mathrm{mg} / \mathrm{kg}) ;$ Kenaf had the highest copper concentration of $(0.030 \pm 0.008 \mathrm{mg} / \mathrm{kg})$. The concentration of zinc in all the vegetables was higher when compared to the other metals (but still fell within the permissible limit); this could be due to the high absorption capabilities of the vegetables to zinc. Lar et al. (2014) who analyzed heavy metals in urban soils and vegetables in Jos metropolis also reported a high absorption capacity of lettuce and spinach for zinc. Zinc is quite essential for human health, its low concentration in humans could cause birth defects, loss of appetite, slow wound healing, and skin sores while its high concentration can also pose danger to unborn and newborn children (Lar et al., 2014). The lowest concentration of lead $(0.025 \pm 0.004$ $\mathrm{mg} / \mathrm{kg}$ ) was observed in Sesamum leaves, the highest manganese level of $0.335 \pm 0.015 \mathrm{mg} / \mathrm{kg}$ was present in spring onion leaves, while spring onion bulbs had the lowest concentration of chromium - $0.020 \pm 0.003$ $\mathrm{mg} / \mathrm{kg}$. Celery and Kenaf were found to contain high levels of arsenic $(0.185 \pm 0.005 \mathrm{mg} / \mathrm{kg}$ and $0.160 \pm 0.017 \mathrm{mg} / \mathrm{kg}$ respectively) which are quite close to the permissible limit of $0.2 \mathrm{mg} / \mathrm{kg}$. Though arsenic is important for growth and reproduction, long-term oral exposure to inorganic arsenic causes dark patches on the skin and cancer (ASTDR, 2007; Bayo et al., 2021). These high levels could be due to the presence of pollutants in the soil on which the vegetables were grown, the use of contaminated irrigation water, or in the agrochemicals administered (Elbagermi et al., 2012).

\subsection{Daily Intake of Metals:}

The result of the Daily Intake of Metals (DIM) from each of the vegetables sampled is shown in Figure 2 while their Maximum tolerable daily intake is shown in Table 4. Comparing the values for the daily intake of metals analyzed in this present study to the maximum tolerable daily intake (MTDI) values reported by Shaheen et al. (2016) (who determined the health risk implications of heavy metals present in fruits and vegetables studied in Bangladesh); only the values for copper in all the vegetables fell below the limit of $30 \mathrm{mg} /$ day. The daily intake values for zinc exceeded the $60 \mathrm{mg} / \mathrm{day}$ limit ranging from $64.268-81.180$ $\mathrm{mg} / \mathrm{day}$. Arsenic and cadmium also exceeded their limits ranging from 5.535-11.378 mg/day and 1.784-5.843 mg/day respectively. The other metals (Mn, $\mathrm{Pb}$, and $\mathrm{Cr}$ ) followed a similar trend. Shaheen et al. (2016) reported mean estimated daily intake values of the sequence $\mathrm{Mn}>\mathrm{Cu}>\mathrm{Zn}>\mathrm{Ni}>\mathrm{Cr}>\mathrm{Pb}>\mathrm{Cd}>\mathrm{As}$; while the sequence exhibited in this study is $\mathrm{Zn}>\mathrm{Fe}>\mathrm{Mn}>\mathrm{As}>\mathrm{Cd}>\mathrm{Pb}>\mathrm{Cr}>\mathrm{Cu}$.

\subsection{Health Risk Index of metal contamination of vegetables:}

The health risk to which humans are exposed from the consumption of these vegetables was determined using the hazard quotient (HQ) and the results are presented in Table 5. The sequence of health risk for the metals analyzed followed the decreasing order $\mathrm{As}>\mathrm{Cd}>\mathrm{Zn}>\mathrm{Pb}>\mathrm{Mn}>\mathrm{Cr}>\mathrm{Fe}>\mathrm{Cu}$. Adedokun et al. (2016) who determined the health risk assessment of heavy metals intake through consumption of some leafy vegetables in Lagos metropolis (Nigeria), reported the health risk sequence of $\mathrm{Pb}>\mathrm{Cu}>\mathrm{Cd}>\mathrm{Zn}>\mathrm{Cr}$. The HQ values for all the metals analyzed in this study except As, $\mathrm{Cd}$ and $\mathrm{Zn}$ were less than one (1), which indicates that the vegetables are safe from health risks that could be posed by those specific metals ( $\mathrm{Fe}, \mathrm{Cu}, \mathrm{Pb}, \mathrm{Mn}$, and $\mathrm{Cr}$ ). $\mathrm{As}, \mathrm{Cd}$ and $\mathrm{Zn}$ had HQ values were greater than 1 in all the analyzed vegetables, they could therefore be considered as potential hazards for the consumers.

\subsection{Conclusion}

This study gives recent information on the heavy metal contents of vegetables commonly sold in Jos Metropolis, Nigeria, and their health implications on consumers. The heavy metals examined were present in all the samples studied, with most of them falling within the FAO/WHO permissible limits. Generally, Zinc concentration was higher in all the vegetables analyzed, when compared to other metals. From the point of view of daily consumption of the vegetables, only copper was below the MTDI level while Zinc exceeded the limit with the highest values and the least was Chromium in the sequence $\mathrm{Zn}>\mathrm{Fe}>\mathrm{Mn}>\mathrm{As}>\mathrm{Cd}>\mathrm{Pb}>\mathrm{Cr}>\mathrm{Cu}$. From the perspective of health risk to humans, the hazard quotient of the individual metals was determined. The HQ of all the metals analyzed was below 1 except As, Cd, and $\mathrm{Zn}$ which were greater. This implies that consumption of vegetables could pose health risks to the consumers through bio-accumulation of these metals in their system. From the outcome of this study, it is recommended that farmers should be sensitized on the detrimental effects of heavy metal pollution and best farm practices should be embraced in vegetable cultivation. The use of persistent agrochemicals, wastewater irrigation, among others should not be encouraged, as these could be the avenues through which heavy metals accumulate in vegetables.

\section{Acknowledgement}

The authors are grateful to the staff of the Biochemistry Division of the National Veterinary Research Institute, Vom, Jos, Nigeria for the assistance rendered in the course of this research.

\section{Conflicts of Interest}

None

\section{References}

1. Adedokun, A.H., Njoku, K.L., Akinola, M.O., Adesuyi, A.A., \& Jolaoso, A.O. (2016). Potential Human Health Risk Assessment of Heavy Metals Intake via Consumption of some Leafy Vegetables obtained from Four Market in Lagos Metropolis, Nigeria. Journal of Applied Science and Environmental Management, 20(3), 530-539. DOI: 10.4314/jasem.v20i3.6.

2. Agency for Toxic Substances and Disease Registry (ASTDR). (2007). Toxicological Profile for Arsenic.https://www.atsdr.cdc.gov/ToxProfiles/tp.as p?id=22\&tid=3. Accessed on 22nd April, 2021

3. Alliea, N. (2014). Heavy metal levels in leafy vegetables from selected markets in Guyana. Journal of Agricultural Technology, 10(3), 651- 663. http://www.thaiscience.info/Journals/Article/IJAT/10934583.p df. 
4. AOAC Official Method. (1975). Metals in plants and pet foods: atomic spectrophotometric method. JAOAC (975.03) 58: 436.

5. Bayo, D., Adeniyi, O., Adeniyi, A., \& Ariwoola, O. (2021). Heavy Metals Concentration and Health Risk Assessment of Selected Fruits sold in Jos Metropolis. Advances in Chemical Research $\quad 3(2)$ : 1-15. Doi:10.21926/acr.2102013

6. Bedassa, M., Abebaw, A., \& Desalegn, T. (2017). Assessment of Selected Heavy Metals in Onion Bulb and Onion leaf (Allium cepa L.), in Selected Areas of Central Rift Valley of Oromia Region Ethiopia. Journal of Horticulture, 4(4), 1-5. DOI: $10.4172 / 2376-\quad 0354.1000217$.

7. Codex Alimentarius Commission (FAO/WHO). (2001). Food additives and contaminants-Joint FAO/WHO Food Standards Programme (ALINORM01/12A, pp. 1-289). http://www.fao.org > input > report > Accessed on 28th April, 2021

8. Cui, Y.J., Zhu, Y.G., Zhai, R.H., Chen, D.Y., Huang, Y.Z., Qui, Y., \& Liang, J.Z. (2004). Transfer of metals from soil to vegetables in an area near a smelter in Nanning, China. Environment International,30, 785-791

9. Dabak, J.D., Solomon, M.D., \& Mafulul, S.G. (2013). Comparative Study of Some Heavy and Trace Metals in Selected Vegetables from four Local Government Areas in Plateau State, Nigeria. IOSR Journal of Environmental Science, Toxicology and Food Technology, 6(3), 86-93.

10. Dafaelseed, M.S., Eltayeb, M.M., Hassan, A.B., \& Babiker, E.E. (2007). Heavy metals and pesticide residue in commercial fresh vegetables in Sudan. Technological Transformation and Competitiveness in the Middle East, XXXX , 1-8.

11. Egharevba, I.P., Aluyor, E.O., Ossai, J.E., \& Oiwoh, O. (2017). Assessment of Heavy Metals Contamination in Vegetables and Fruits Sold in Benin City, Edo State, Nigeria. Nigerian Research Journal of Engineering and Environmental Science, 2(1), 161- 168.

12. Elbagermi, M.A., Edwards, A.G.M., \& Alajtal, A.I. (2012). Monitoring of Heavy Metal Content in Fruits and Vegetables Collected from Production and Market Sites in the Misurata area of Libya. International Scholarly Research Network, 1-5. Dsoi:10.5402/2012/827645

13. Jaishankar, M., Tseten, T., Anbalagan, N., Mathew, B. B., \& Beeregowda, K.N. (2014). Toxicity, mechanism and health effects of some heavy metals. Interdisciplinary Toxicology, 7(2), 60-72. doi:10.2478/intox-2014-0009

14. Jolly, Y.N., Islam, A., \& Akbar, S. (2013). Transfer of metals from soil to vegetables and possible health risk assessment. SpringerPlus, 2(385), 1-8. Doi: 10.1186/2193-1801-2-385

15. Joseph, D.O., Egila, J.N., \& Salami, S.J. (2016). Determination of the Contamination Levels of Cadmium, Lead, Arsenic, and Mercury in the Vegetables from Old Mining Site of Jos Plateau, Nigeria. International Journal of Interdisciplinary Research and Innovations, $\quad 4(2), 40-44$.

16. Lar, U., Shettima, E., \& Dibal, H. (2014). Heavy metals in the urban soils and vegetables in Jos metropolis, Nigeria: Implications on children's health. American Journal of Environmental Protection, 3(6-2), 70-76.

17. Lenka, J.L., Lepzem, N.G., Mankilik, M.M. \& Dafil, R.P. (2018). Heavy metal contamination in selected cruciferous vegetables grown in Jos, Nigeria. International Journal of current research In Chemistry and Pharmaceutical Sciences, 5(4), 26-34. DOI:

18. Mafuyai, G.M., Eneji, I.S., Sha'Ato, R., \& Nnamonu, L.A. (2019). Heavy Metals in Soil and Vegetables Irrigated with Ex-Tin Mining Ponds Water in Barkin-Ladi Local Government Area Plateau State, Nigeria. American Journal of Chemical Research, 3(15), 1-17.

19. Nigerian Meteorological Agency (NIMET). (2017). Weather of Jos-Plateau.

20. Njoku, K.L., Ezeh, C.V., Obidi, F.O., \& Akinola, M.O. (2017). Assessment of Pesticide Residue Levels in Vegetables sold in some markets in Lagos State, Nigeria. Nigerian Journal of Biotechnology, 32, 53 -60. DOI:

21. Ogundiran, M.B., \& Osibanjo, O. (2008). Heavy metal concentrations in soils and accumulation in plants growing in a deserted slag dumpsite in Nigeria. African Journal of Biotechnology, 7(17), 3053-3060.

22. Onakpa, M.M., Njan, A.A., \& Kalu, O.C. (2018). A Review of Heavy Metal Contamination of Food Crops in Nigeria. Annals of Global Health, 84(3), 488-494. DOI:.

23. Regional Screening Level (RSL). (2020). Summary Table.

24. Shaheen, N., Irfan, N.M., Khan, I.N., Islam, S., Islam, M.S., \& Ahmed, M.K. (2016). Presence of heavy metals in fruits and vegetables: Health risk implications in Bangladesh. Chemosphere, 152, 431- 438.

25. Sharma, A., Katnoria, J.K., \& Nagpal, A.K. (2016). Heavy metals in vegetables: screening health risks involved in cultivation along wastewater drain and irrigating with wastewater. SpringerPlus, 5(488), 2-16

26. Singh, R., Gautam, N., Mishra, A., \& Gupta, R. (2011). Heavy metals and living systems: An overview. Indian Journal of Pharmacology, 43(3), 246. doi:10.4103/02537613.81505 .

27. Slavin, J.L. \& Lloyd, B. (2012). Health Benefits of Fruits and Vegetables. Advances in Fruits and Vegetables, 3(4), 506- 516.

28. Tasrina, R.C., Rowshon, A., Mustafizur, A.M.R., Rafiqul, I., \& Ali, M.P. (2015). Heavy Metals Contamination in Vegetables and its Growing Soil. Journal of Environmental Analytical Chemistry, 2(3), 1-6.

29. Tchounwou, P.B., Yedjou, C.G., Patlolla, A.K., \& Sutton, D.J. (2012). Heavy Metals Toxicity and the Environment (NIH Publication) 101, 133-164. DOI:10.1007/978-3-76438340- 4_6.

30. U.S. Environmental Protection Agency (US EPA). (1989). Risk Assessment Guidance for Superfund (Human Health Evaluation Manual [part A]: Interim Final). U.S. Environmental Protection agency, Washington, DC, USA [EPA/540/1-89/002]

31. US Environmental Protection Agency (US EPA). (1997). Exposure factors handbook-general factors (Office of Research and Development). National Center for Environmental Assessment. Washington, DC: US Environmental Protection Agency EPA/600/P- 95/002Fa, vol. 1.

32. US Environmental Protection Agency (US EPA). (2015). Human health risk assessment: risk- based concentration table.

33. Wilbur, S., Abadin, H., Fay, M., Dianyi, Y., Tencza, B., Ingerman, L., Klotzbach, J., \& James, S. (2008). Profile for Chromium. Agency for Toxic Substances and Disease Registry (ASTDR). Atlanta Georgia USA. National Center for Biotechnology Information (NCBI), 417-425 
(cC) (†)

This work is licensed under Creative

Commons Attribution 4.0 License

To Submit Your Article Click Here: Submit Manuscript

DOI: $10.31579 / 2694-0248 / 072$
Ready to submit your research? Choose Auctores and benefit from:

* fast, convenient online submission

* rigorous peer review by experienced research in your field

* rapid publication on acceptance

* authors retain copyrights

* unique DOI for all articles

* immediate, unrestricted online access

At Auctores, research is always in progress.

Learn more auctoresonline.org/journals/archives-of-medical-casereports-and-case-study 